\title{
Evaluation of Internal Control Units for the Effectiveness of Financial Control in Administrative Government Units: A Field Study in Jordan
}

\author{
Dr. Omar Mohammad Al-Hawatmeh \\ Assistan Professor, The University of Jordan, Jordan \\ Dr. Zaid Mohammad Al-Hawatmeh \\ Assistant Professor, Al-Zaytonah University, Amman, Jordan
}

doi: 10.19044/esj.2016.v12n13p225 URL:http://dx.doi.org/10.19044/esj.2016.v12n13p225

\begin{abstract}
The aim of this study is to state the assessment of internal control units for the effectiveness of financial control in administrative government units. Also, it aims at identifying the obstacles that limits the evaluation of internal control units for the effectiveness of financial control in administrative government units. In order to achieve the objectives of the study and the testing of hypotheses, the researcher designed a questionnaire. This questionnaire was distributed to managers and employees in the internal control of the administrative government units. Out of the 125 questionnaires distributed, 96 were recovered with an adoption rate of $77 \%$. The results showed that the assessment of internal control units for the effectiveness of financial control in administrative government units typically became high with an arithmetic mean (4.099) and standard deviation (0.511). The researcher attributed this result to the data analysis, verification, and validation of the financial transactions. Also, accounting entries which is related to income and expenditure were in accordance with laws, financial regulations, and the prescribed accounting for financial controls. Hence, this is the constraints that limit the effectiveness of the auditors of the Audit Bureau when they conducted financial and managerial control and evaluation in administrative government units. Generally, it became high with an arithmetic mean (3.551) and a standard deviation (0.610). Thus, the researcher attributed this result to the existence of certain obstacles, the most important routine work, lack of incentives and benefits, and others as indicated in the results of the study. Based on the results of the study, the researcher recommended the need for attention to the human element as one of the main components of internal control system. This is in terms of training and development to keep pace with scientific progress and the practical need to emphasize the reformulation of some legislation. Also, it
\end{abstract}


helps with some of the aspects due to the need for harmonization between legislation. In addition, it helps with professional international standards, especially supreme control standards which give importance and effectiveness to financial control and other recommendations.

Keywords: Control, internal control, financial control, administrative government units

\section{Introduction}

Internal control units have gained importance especially in the public sector. This is as a result of its public interest and the preservation of government assets. However, this usually reflects the public funds. Hence, since public money represents a cornerstone in the survival of any country, only the internal control units became the first line of defence for protecting and managing government assets. It also helps to prevent them from manipulation and corruption which is a usual occurrence in the government sector (Ghneimat et al., 2011).

Jordan as other countries requires the control of public money. Article 119 of the Jordanian Constitution according to the Audit Bureu law states that "in order to monitor the government revenues expenditures and methods of dispensing, a report should be submitted to the Parliament. It should include the views and comments statement of offences and liability implications at the start of each regular session. Also, whenever requested, deputies to the President of the foundation of any financial system should provide accurate control and organization. This should be in consensus with the economists, financial units, and administrative unit to help government control devices (such as Audit Bureau and the Anti-corruption Commission and other Supreme Regulators).” (Gaith, 2002)

\section{Importance and Objectives of the Study}

The on going development of the public sector and the broad umbrella of the public sector from one year to another have led to increased attention to internal control in the administrative units. This is accomplished through the mechanism of action and procedures for accessing the primary goal of protecting government assets embodied in public money. This protection includes the protection from theft and loss, intentional and unintentional use of money, and in ensuring financial data accuracy due to financial and administrative decision-making.

The transformation and the change in some of the audit bureau control procedures, particularly detailed control to experimental control (sampling method), cancels the previous audit and stay on the subsequent audit. However, this requires the need to emphasize the existence of an 
effective internal control system in all fields. Thus, this is done so that financial control and evaluation can be relied upon and trusted (Arab Group of Supreme Accounting and Financial Control in 2010, p. 210).

The importance of this study can be seen based on the findings and recommendations of internal and external oversight bodies in the process of evaluating the effectiveness of financial control and dependable in their reports. Also, there are important enhancements that can be added to the mechanism of internal control procedures from one year to another. Thus, this eventually leads to the achievement of the overall objective of this study. These includes to protect government assets of public waste and loss, and not the optimal utilization and exploitation as priorities.

The study aims to evaluate the statement of internal control units for effective financial control in administrative government units. Furthermore, it also aims to identify impediments in assessing internal control units for effective financial control in administrative government units.

\section{Study Problem}

Control operations are in accordance with the plans and programmes of the Ministry of finance. It aims to activate and develop the role of internal control and to increase performance. Consequently, it improves the efficiency of the regulatory process under these directives which are binding on all government agencies to protect government assets. It also helps in discovering any early irregularities or deviations. However, the aim of this study is to assess the internal control units for the effectiveness of financial control in administrative government units.

The study aims to answer the following questions:

1. Is it possible to assess the internal control units for the effectiveness of financial control in administrative government units?

2. Are there constraints that limit the assessment of internal controls for the effectiveness of financial control in administrative government units?

3. Are there statistically significant differences in the sample answers due to the experience, qualifications, and position regarding the effectiveness of financial control in administrative government units?

\section{Development of Hypotheses}

In order to answer the questions of the study, the study is based on three hypotheses which is as follows:

H01: Internal control cannot assess the effectiveness of financial control in administrative government units.

H02: There are no impediments limiting the assessment of internal controls for the effectiveness of financial control in administrative government units. 
H03: There were no statistically significant differences in the study sample answers attributed to the experience and qualifications, and the position regarding the effectiveness of financial control in administrative government units.

\section{The Study Population and those Appointed}

The study population consists of all managers and employees in the internal control units in Administrative Government Units. The large population of the study sample represents the largest volume of spending (earmarked allocations). It also represents a greater revenue volume (Revenue units) which is included in the general budget of the government. This is dependent on the relative importance of each of the volume allocations and the size of the revenue by calculating the proportion of spending (current and capitalism to the total public expenditure of the government for 2015). Revenues represent more revenue units for major government imports. Therefore, the study sample represents five spending Ministries for the general expenses of the government, and two revenue Ministries for imports government (finance, education, health, public works, housing, social development). The administrative department is represented by the income and sales tax department, Jordan Customs.

The researcher distributed questionnaires to all members of the sample (125) personally and recovered 100 of the questionnaires. Furthermore, it shows the validity of the questionnaires recovered to be valid for statistical analysis purposes (96) at a rate of 0.77 . Thus, this is sufficient to rely on the analysis and results.

\section{Data Sources}

-Secondary Data Sources: This source is relied upon by the researcher to obtain secondary data, such as books, periodicals, articles, and electronic information network.

-Primary Data Sources: The researcher often depends on the resolution of initial data collection categories used in the study. Hence, this will be developed based on the elements of the problem study and assumptions.

\section{Literature Review}

Many previous studies were conducted for the assessment of internal control units for the effectiveness of financial control in administrative government units. Thus, below are some relevant studies: 


\section{Robyn Pilcher (2014) Study}

Role of Internal Audit in Australian: Local Government Governance - A Step in the Right Direction

This study aimed to release the basic role of the Australian government to provide effective performance in internal audit and related disciplines that play a key role in ensuring effective professional performance.

With the advancement in accounting on accrual basis, Australian Government have added emphasis to the risks of complicated fraud, corruption cases, and high-risk investments in many local Australian councils reported periodically by the media.

Subsequently, these cases were accompanied by the proposed reforms, including the introduction of the internal audit function to address issues raised. Therefore, it is regarded as an essential part of the work.

The study used a descriptive analytical questionnaire prepared and distributed to local councils. Furthermore, the study sample is represented by the chief financial officer and members of the local Australia councils.

The results of the study proved that there is still some confusion on the role of internal audit. As a result, it considers its effectiveness in local Australian government. The internal audit function is designed to manage documents and standardization of internal controls across all functions of the council (Chief Financial Officer, the Board). The internal audit function was focused on things the councils must do to get correct reports. Internal Auditor function has different duties, but is not limited to blogging.

\section{Sawalha et al. (2013) Study}

Modernization of Higher Government Control Methods according to the Requirements of the Privatization: A Case Study in Jordan

This study aims to examine the understanding and recognition of the supreme financial control to keep pace with scientific developments that may occur in the government's internal management. Thus, this was after the restructuring of the financial and economic departments due to privatization and expansion of the private sector and the GATT. This study does not allow the emergence of gaps through financial loss or waste of public money because of broad spending. It keeps the old methods of auditing and control and manual operation of the data before the privatization and restructuring of some economic sectors. It is achieved by developing new programmes and strategies to implement their plans based on international audit standards and performance audit or extensive electronic data in different stages of departmental financial and economic structures.

The researcher adopted both the inductive and deductive approach together. This study is a kind of descriptive exploratory survey based on the 
views or trends in the study sample. However, this study was conducted on a sample of accounting departments' staff in government departments.

After applying the study tool, the study sample responses were collected and converted to raw scores. After then, the duplicates, percentages, arithmetic averages, and standard deviations were obtained. Ttest is used to find the differences between the estimates sample members to senior government control methods systems according to the paragraphs of the resolution as the level of statistical significance $(\alpha=0.05)$.

The study found a range of outcomes, including:

1. Regulators Supreme which represents accounting Bureau Practiced control over the privatization process.

2. The privatization policies are the result of international pressure to restructure and correct the Jordanian economy.

3. There is an urgent need to modernize control methods carried out by the upper neck destinations and strategic planning for Supreme Control views.

\section{Rashid Hamdani \& Al-Araji (2012) Study:}

The Effectiveness and its Impact on Financial Corruption and Financial Control System in Iraq - A Case Study on the University of Mosul

This study aimed to show financial corruption, suffered by countries, especially developing ones including Iraq. It identifies shortcomings and weaknesses in financial controls that could be exploited for the purposes of financial corruption. Also, it took a broad dimension of various factors, including regulatory agencies. Therefore, the search is based on assessing and measuring the effectiveness of regulatory agencies of the University of Mosul research sample. This sample was selected for the purpose of diagnosis, and it serves as a bridge for the entry force of corruption. The study questionnaire is used as a tool to collect and distribute data. However, 20 copies of the questionnaire were distributed to employees in the internal control units of the University of Mosul. The study population consisted of all units of internal control (41 units) at the University of Mosul. Also, it comprises of a stratified random sample of 23 College where 50 questionnaires was distributed. Out of the 50 questionnaire distributed, 40 of them was retrieved. They are valid for statistical analysis which represents $82 \%$ of the study sample.

In this study, the researcher depends on the way that is applied by the Financial Control office on measuring the effectiveness of the internal control system. However, the research on statistical method adopted includes:

- The degree of effective control system is equal to the form answer divided by standard values multiplied by $100 \%$. 
- Percentages and arithmetic, and the use of the style of Z statistical test for personal judgment.

The study found the following results:

1- Causes of corruption on two main aspects related to the same individual. First, it is driven by circumstances and its own environment, and the second issue is the reasons beyond the control of the individual that make it easier to engage in financial corruption, foremost of which is the weakness of financial control.

2- All Iraqi ministries and government departments including the Ministry of Higher Education still suffers from corruption.

\section{Abo Dalobh (2012) Study}

The impact of Effective Financial Control over the Financial Performance of Independent Public Institutions of Jordan

This study aimed to determine the impact of effective financial control devices in Jordan on the financial performance of independent public institutions. It also states the importance of independent financial regulatory control on the financial performance control of public institutions. It measures the extent of the need for an effective watchdog in Jordan to carry out its responsibilities. Furthermore, it considers the need to carry out these tasks in ways that ensure the achievement of the desired objectives.

Therefore, the study depends on descriptive and analytical approach to analyze the dependent variable and measures how it relates to the independent variables. It is a descriptive study of the analytical data on the linkage between external financial control and the financial performance of independent public institutions.

The study used a questionnaire as a tool for collecting data. The questionnaire was distributed to a random sample of employees in the financial departments and the internal control units of independent public institutions, and those who control those institutions in government financial control entities (Audit Bureau).

The study sample consisted of 19 independent public institutions. Also, it includes the views of a number of employees in the financial departments and the internal control units of independent public institutions. They are responsible for the external financial control of the government regulators concerned with financial control over those institutions of the Ministry of finance and Audit Bureau.

The study used a number of statistical techniques, including descriptive statistics, which consists of frequencies, percentages, arithmetic mean, and standard deviation. It is also used for the T single-sample test and for the analysis of variance to test the hypotheses of the study.

This study found a range of results: 
1- Legislation which governs the financial operations and regulates proceeding in independent public institutions has a positive impact on the financial performance of the financial departments of independent public institutions.

2- The extent of the rehabilitation of those cadres has a positive impact on the financial performance in the financial sections in independent public institutions

3- The effectiveness of financial control has a positive impact on the ability of financial institutions to minimize deviations of actual expenditures from the budget estimate and for achieving the rationalization of spending.

4- The level of external financial controls in the same direction affect the financial performance as measured by the existence of internal control unit for internal control and the availability of various manifestations of internal control assessment and periodic review.

5-The financial control and the results of the external periodic financial control work results have a positive impact on the financial performance of independent public institutions as measured by compliance and output accounting convenience.

6- The financial performance in independent public institutions is affected by the direction and is at the same level of external financial control of governmental entities.

\section{Gerrit Sarens (2007) Study}

The Role of Internal Auditing in Corporate Governance Qualitative and Quantitative Control on the Influence of Organizational Characteristics

This study aimed to examine the "Role of Internal Audit in corporate governance", which focused on discussing the impact of organizational characteristics as input quantity and quality. Therefore, this is performed under the role of internal audit in corporate governance activation which adopted the analytical and descriptive method in public shareholding companies.

Some of the most important results are:

1. The overall level to preserve shareholders' equity can be increased through the integration of internal and external audit functions.

2. Senior management decisions have a significant impact on the performance of the internal audit work.

3. This revision was able to intereview most of the decisions of senior management, which in turn provide support and assistance to internal audit.

\section{Cahill (2006) Study}

The Effectiveness of the Audit Committee and Internal Audit in a Branch of an International Bank: A Case Study of National Irish Bank (NIB) 
This study aimed to identify the effectiveness of the internal audit and the Audit Committee of the Bank through a case study of National Irish Bank (NIB).

This study was characterized by high credibility because of the access to information from the supreme bodies. It obtained information from published reports from the Ireland's government and parliamentary committee government accounts. In addition, some information was obtained from inside the bank, as well as by reference to court cases that is pending against the bank. Consequently, this indicated the presence of illegal transactions with clients of tax evasion and concealment of facts. The study covered a period of 10 years ending. In 1998, it adopted a descriptive study in Ireland. Thus, the study found the following results:

1. The study shows that the internal audit system and the Audit Committee were aware of the existence of these problems and abuses, but they were not treated safely and correctly.

2. The study predicted that the international bank is subject to strong control of more than one perspective and the parent companies abroad, but this study showed the failed missions of the audit committees.

\section{Janta et al. (2005) Study}

Interal Auditing Practices and Internal Control System

This study aimed to determine the level of commitment included in the financial market. Malaysia's Internal Auditing issued by the Institute of Internal Auditors (IIA), as well as whether to adhered to these standards affects the internal control systems in these companies. The study depends on a method of descriptive statistical analysis to describe and analyze the study variables and the testing hypotheses.

Therefore, the study concluded with a set of results, including:

1- Professional and objective internal audit departments in companies listed in the Malaysian stock market for securities companies significantly affected the efficiency of the internal control systems.

2-The scope of internal audit and professional performance of internal audit departments have an effect on the attributes of Communication and Media's internal controls and the features of the internal control system environment system.

3-The internal audit management process performs the audit work plan. Also, the internal audit report on the work of internal audit can significantly affect the risk assessment attributes of the control system.

\section{Kevin (2003) Study}

The Effects of Internal Audit Structure on Perceived Financial Statement Fraud Prevention 
This study aimed to investigate the impact of internal audit structure on the prevailing impression among users of financial statements. The study focused on the independence of the auditor and its role in improving the work plan of the audit carried out in the United States. However, the role of the internal audit function to prevent financial fraud in the United States was estimated. The designed questionnaire fit into the theme of the study. Thus, its objectives have been distributed to all employees in the units of internal audit. The study adopted a method of descriptive statistical analysis to describe and analyze the variables of the study and the testing of the hypotheses.

However, the study found the following results:

1- The impression among these officials is that the internal auditors under the guidance of their reports to senior management at the center cannot enable them to reduce fraud financial statements.

2- The Guide reviewers reported to the Board which were at the center of a greater autonomy result as they can reduce fraud for financial statements.

3- The study did not show differences in the prevailing impression when you reduce the possibility of fraud financial statements dating back to the audit function. This function is obtained from within the company or from an external source, especially when the reports are forwarded to the Audit Committee of the Company.

\section{O'Regan \& David (2001) Study} Auditing

Genesis of a Profession toward Professional Status for Internal

The study aimed to clarify the concept of professionalism in the internal auditing profession and to clarify the role of the Institute of Internal Auditors in promoting occupational and professional internal audit. The study depends on descriptive and analytical approach by studying the standards of the IIA issued according to international standards in the field of government censorship. Questionnaire have been designed and distributed to all employees in the units of the Internal Audit. However, the study relied on a method of descriptive statistical analysis to describe and analyze the variables of the study and the testing of hypotheses.

One of the most important results of this study can be seen from the following conclusions:

1- The presence of the constituents of such ingredients is summarized as knowledge of the social and institutional legitimacy formed. It is formed based on a convenient and an appropriate centered ethics framework.

2-The Institute of Internal Auditors (IIA) has gone a long way to reach the professional recognition of internal audits across its inception to 
learn to maintain autonomy from the other knowledge. Dedication to the institutional framework includes formal institution and Institute professional certification issued by the literature, periodicals, and magazine. Also, research activities are enabled by the addition of written standards that has circulated and ethics and behaviors of the profession. However, the researcher acknowledged that more steps should be taken into account. This is regarded as the full recognition of independent craft for someone known as internal auditors.

3- The importance of internal audit section tries to emphasize the independent profession. They do not address the concept, objectives, scope, and responsibilities of the profession; its role in improving the administrative and financial performance; and its role in supporting the control systems and risk management facility.

\section{Smith Jones (2000) Study}

Strengthening Internal Controls

This study aimed to illustrate various ways to strengthen internal controls in the organizations and their importance, especially in the field of preventing and detecting errors, fraud, and mismanagement. The study depends on descriptive and analytical approach. A questionnaire was also prepared and distributed in coordination with the organizations in the United Kingdom and Australia.

One of the most important findings of the study includes:

1. Internal control weaknesses would result in serious consequences. Thus, the most important is the lost through neglect and lack of attention.

2. Wastefulness resulting from deficiencies in the procedures and regulations, decisions, and misuse through the exaggeration of the proceedings and mismanagement.

3. The study concluded that the possibility of fraud does exist, and that good internal control program-on paper-does not guarantee the commitment of individuals to control procedures.

4. The effectiveness of the internal control program is a managment responsibility. Thus, this was done so that there were no participation of governance at all levels. Therefore, the internal control system would not be effective.

\section{Theoretical Framework Internal Control}

The internal auditor in the public sector is required to assist the administrative government units to improve their operations. Various public sectors lend increasing importance and value to the common understanding of autonomy as a basis for the credibility of the auditor. Therefore, the 
internal control function could be organized and implemented on several levels within the administrative units.

Internal control is defined as a set of methods and procedures used to develop efficient regulation and promote acceptance of sound policies and procedures in the Commission. This is used for checking the validity of information management, protection of assets, and for minimizing mistakes (ARABOSAI, 2012).

It was also defined by complex internal auditors. The Institute of Internal Auditor's latest definition of internal auditing can be defined as an independent objective assurance and consulting activity designed to add value and improve an organization's operations. It helps an organization to accomplish its objectives by bringing a systematic and a disciplined approach in evaluating and improving the effectiveness of risk management, control, and governance processes (IIA, 2011).

Also, the Audit Committee methods of auditing procedures which emanated from the American Institute of Certified Public Accountants (AICPA), defined internal control as "organizational plan and all methods and procedures developed by the company management, which aim to preserve the company's assets and ensure the accuracy and correctness of accounting information, increase the reliability and operational efficiency, and to verify the employee commitment to administrative policies set by the administration.” (ARABOSAI, 1996)

\section{Internal Governmental Control}

This refers to those that are within the same administrative governmental unit in various units and sections by the administrative government unit. They aim to follow up its interior, to correct the wrong businesses, evaluate completed work, and identify deviations in the methods and procedures designed to safeguard its assets and property. Hence, this is for the purpose of ensuring the accuracy of accounting and statistical data. This is in a bid to raise productivity in administrative government units and achieve its objectives.

In addition, it helps administrative government units to achieve objectives through a systematic disciplined approach for evaluating and improving the effectiveness of risk management procedures and financial control (Al Dosari, 2012).

\section{Objectives of Internal Control}

The most important objectives of internal control (Abu Dalbouh, 2012) include:

1- Protect assets and reduce the incidence of fraud and errors discovered, and the accuracy and completeness of the accounting records. 
2- The effectiveness and efficiency of the operations carried out by the departments and employees.

3- Compliance with laws, regulations, and policies adopted by the administration to achieve the goals established.

\section{Elements of the Internal Control System}

Internal control system is an organizational plan for a range of actions and issues adopted by the facility which consists of basic elements. However, these elements must be provided by management and committee in order to achieve its objectives (Rashid, 2012). They are:

\section{Separation of Responsibilities}

An established department must separate the responsibilities of their employees, and even reduce possible fraud or inadvertent errors in the financial statements and management. Thus, it is based on this assumption hard collusion between employees or more is used in the implementation of manipulation or hides any unintentional errors.

If proper separation between the responsibilities of employees depends on the separation of the functions of retained assets or possession of the evidence in the records and the certification authority (i.e. workers who have the authority to authorize operations), the cashier who keeps cash and account manager and his staff are doing a job of proof in the records. The Director of the Administrative and Financial Department approval of the job is the financial director of the administrative department. Thus, it is the person responsible for granting approvals.

\section{Clear Lines of Authority and Responsibility}

Large number of employees performs various functions in the facility. In order to achieve effective control over all the jobs, they must be held accountable through the allocation of specific responsibilities to specific individuals. In addition, it must be done through the manual mode (job description and powers), which should be known and not available to all employees.

\section{Administrative and Organizational Plan}

The system depends on the presence of an organizational plan and specific management objectives which clarifies the overall framework to guide and adjust the institution activity. This is done by having an organizational structure capable of clarifying authority's policies, determine responsibility, and provide procedures which do not allow anyone to breach internal control system through the creation of a clear link between the different functions. 


\section{Accounting System}

Accounting system is based on an integrated set of documents, records, and classifieds evidence for calculations taken into account. Generally accepted accounting principles, documents, and records are considered as an essential foundation for documenting an enterprise's operations and information source for management decision-making. In addition, it aims at benefiting from the parties. Also, the statements cannot imagine the success of any facility in the provision of information without installing its operations in documents and in the records of any of its employee's memory.

The document is the beginning of the accounting system point. It contains the necessary data to prove the placement of each process in the institution. They are documenting what is going on from the activities and daily operations. Based on registration records and the issuing of various reports required by management or third parties (externally), great care should be taken by the employee.

Group accounting books is the basic support of the accounting system. Thus, it is considered as a tool for recording, analysis, and presentation. Furthermore, it also serves as a means for the preparation of financial statements and various reports that serve multiple objectives.

Group accounting books is divided into two sub-categories:

Accounting Records: This records the accounting entries which are the basis for the preparation of financial statement and analytics financial reporting.

Statistical Records: This records all extra data that is needed to create a database to help management in the various decision-making processes. In addition, it also helps management to solve administrative problems.

\section{Protect Assets and Records}

Institution must have the necessary Capabilities and procedures to protect and prevent all of the assets and records from damage, loss, waste, and misuse. Therefore, this is done through written instructions shown through work methods, protection procedures, and the follow-up personnel's commitment to these instructions. Thus, these instructions include saving money procedures and deposit in the bank, and the procedures for organizing stores. In addition, it helps to protect them from theft and manipulation, as well as fixed assets.

For the records, it must be kept in places to prevent unauthorized access and make illegal adjustments. Also, a second copy of the records should be kept in the case of possible work. 


\section{The Efficiency and Integrity of Staff}

The effectiveness of internal control depends on the efficiency and integrity of the employees in the institution. Thus, this is despite the clarity of authority, lines of responsibility, and the correct distribution of jobs in accordance with the internal control system. However, there is a failure of any system in achieving its objectives due to inefficiency of the secretariat staff in the institution to perform the responsibilities entrusted to them.

Internal control system may be a good and effective to talented and qualified staff and Trustees. Although this system does not include specific detailed functions and authorities, it must therefore follow institution policy in hiring new employees or upgrade existing employees. This is done by taking into consideration the job description and qualifications required for occupancy jobs.

Types of Internal Control in the Public Sector (Alkaaabr, 2013)

1- Financial Audit: It is intended to analyse the economic activity of the institution and the assessment of accounting and information systems, financial reports, and reliability. 2-Compliance Audit: It is a review of controls (financial and operational) to judge the quality and appropriateness of systems that have been developed to ensure compliance with regulations, legislation, and the policies set by the administration and procedures.

3- Operational Audit: It is a comprehensive review of the various functions within an organization (such as sales, purchasing, production, accounting, maintenance etc.). This is aimed at ensuring the efficiency, effectiveness, and suitability of these jobs in achieving the objectives of the institution.

\section{Factors Affecting Internal Control Systems in Government Units (Genimat \& Siam, 2011) Evaluation and Updating the Internal Control System}

Management resort for continuous and periodic internal quality control performance is used to determine the extent of implementation of control in the design topic. It determine the possibility of modification and development which also suits the changes in the surrounding environment.

\section{Follow-up Commitment to the Internal Control System}

Internal control will not be achieved unless the unit's personnel is committed to the application of laws and regulations, directives and administrative policies, and assess to their performance continuously. Usually, the administration follows-up the commitment of employees and 
evaluates their performance through audits, monitoring, evaluation, and reporting on the results of their work to senior management.

\section{Internal Control Reports}

The internal auditor's report is the last step. It is important in reporting the results of audit operations and various activities. However, it also reports the imbalances and deficiencies in the internal control system and the areas of non-compliance with laws, regulations, instructions, and alert management risks (Ghneimat \& Siam, 2011).

Auditor's report includes the most important observations which were discovered by internal auditors. Subsequently, the note includes the following corners (Abu Dalbouh, 2012):

1- Identification of offense or imbalance which are attributed to laws and regulations and the administrative policies, norms, and standards of internal control system.

2- $\quad$ Negative impact that occurred because of the offense or the defect, or the negative impact statement that is likely to happen.

3- Recommendations to avoid offending or damage, or demand management to take corrective action or a deterrent to prevent the recurrence of such violation.

\section{Financial Control}

In recent years, the growing sophistication of financial control has been observed in the Hashemite Kingdom of Jordan. This is common especially in the various areas of the social and economic sector. Furthermore, it plays a significant role in emphasizing the need for the profession of accounting and auditing as tools for financial control of public money.

\section{Financial Control Definition}

A comprehensive scientific approach requires integration between legal and economic, and accounting and administrative concepts for the purpose of ensuring the conservation of public funds and in raising the efficiency and effectiveness of the results achieved. However, this task is performed on behalf of an independent legislative power and an unaccountable executive (INTOSAI, 2006).

The Arabic organization of Supreme financial control define financial audit manual as a "verification of the implementation of the budget allocations in the faces and for advanced adopted financial allocations within the rules during specific time periods, so as to ensure that public spending is within limits of the appropriations allocated to the purposes for which it was allocated as intended in general to verify that there are no waste or 
squandering of public funds in order to identify weaknesses and errors and avoid repetitions." (ARABOSI, 2012)

The concept of Supreme financial control was developed with the development of the concept of managing public money. It involves the Supreme control of fianaces at early stages by regular surveillance of known dimensions legality and accounting. However, this ensures the safety of the procedures applied by the government in maintaining public money and good adherence to the laws and regulations in force.

Paragraph 132 of the financial control of the international organization of Supreme financial control bodies (INTOSAI code) states that: "Controller must have a planned Financial Supervisory style confirming that it had been done under the control of a quality, highly economical, efficient, and effective way in a timely manner.” (INTOSAI, 2003)

\section{Financial Control Objectives}

The main objective of financial control is to provide assurances in all areas of concern to the government departments. It was concluded that financial control is responsible for the numbers in the accounts. Therefore, they are reliable and efficient systems. Also, they ensure that government expenses are consistent with the conditions laid down as laws. This compatibility is an important part of the principle of regularity which is based on checking the accuracy of the figures, legal and regularity of the transactions, and is known as the process of ratification by the auditor (Alkaabr, 2013).

Consequently, financial control objectives can be summarized below as follows (al Dossari, 2011.36-37):

1- Protection of public money and rationalize expenditure, and discovering cases of fraud, theft, and embezzlement.

2- Ensure the health, safety and accuracy limitations, financial documents, data rotating and non-rotating, and records so that it can be relied upon in making decisions.

3- Verify the validity and integrity of the conduct of financial matters and the application of Laws, regulations, instructions, and financial policies in public institutions.

4- $\quad$ Ensure that administrative decisions with financial implications are strictly enforced according to the laws, regulations, and instructions in force. 5- $\quad$ Provide evidence for administrators, decision-makers, and work to uncover cases of financial and administrative side of weakness in the institutions.

6- Determine the duties and responsibilities and identify deviations kind, either positive or negative, for the development of procedures and appropriate measures for each type. 
7- Ensure that all laws, regulations, instructions, and decisions applicable are taken into account by all employees in the organization.

8- $\quad$ Improve the quality of public administration and public enterprises.

9- Suggest ways of minimizing the chances of making inappropriate decisions.

10- Judging the adequacy of internal controls systems applicable to the entities controlled and their efficiency in achieving the goals both efficiently and effectively.

11- Identify shortcomings and success in the audited entity.

\section{The Importance of Financial Control in the Government Sector}

The importance of financial control is to represent and ensure the proper implementation of fiscal policies. Thus, it is used to achieve the goals relating to the credibility and fairness of the financial statements and the accuracy of financial reports submitted to it. This is done in order to protect the assets of manipulation and misuse by helping to correct tracks and distractions during the execution of the plans efficiently (Arabosai, 2000, 17).

The importance and need of financial control increases by increasing the size of the administrative units and the multiplicity of its activities and programs. This importance includes the following (Rashid et al., 2012.327):

Firstly: Politically, it is used to ensure respect for the Parliament volition in the financial implementation of laws and their quest to enforce the nation volition in the use of their funds and employment.

Secondly: Financially, it is used to prevent extravagance, waste, and misuse of public funds and by commitment appropriations by monitoring specialist's expenses contract and revenue collection.

Thirdly: In accounting terms, it is used in ensuring compliance with standards, principles, integrity of the data, and accuracy of accounting.

Fourthly: Economically, it monitors the performance of authorities' activity based on the implementation of the general budget, in terms of cost and time.

Fively: Legally, it reflects its importance in penalties on perpetrators of errors and deviations.

Sixly: Socially, it limits the spread of the culture of corruption and violating of the public money.

As previously noted that multi-purpose areas give financial control, there is a great capacity to adapt to environmental changes (large size of organization, unemployed time, waste of public money, consistency with organizational complexity, and reduction in errors and other environmental changes that can occur inside the unit). 
Functions, Responsibilities, and the Action Mechanism of Financial Control Unit in Administrative Government Units (Hashimiate Kingdom of Jordan- CSB0, 2013)

Inspection, verification, and evaluation of all activities are related to the safety and validity of financial transactions, behaviours or procedures, or human and material elements of production.

-Check and make sure that the resources have been collected and documented records are used on the dials planned. objectives.

-Verify compliance with plans, performance standards, and

-Verify that the assets, property, and production elements have been mixed, purchased, created, employed, or used in accordance with specifications, standards, plans, and has been approved.

-Be sure to provide all possible means of safety production and maintenance, protection, and preservation.

-Make sure that the use of factors of production and work procedures were in accordance with applicable legislation. and files.

-Verification, validation and fundamentalist of records, documents

-Check and make sure that financial guarantee for tenders are in conformity with applicable regulations and instructions, and update timestamps.

-Evaluation of performance in all business areas.

-Participation in the work of the committees commissioned by the associated unit.

-Access to data and information on the scope of the tasks entrusted to the unit.

-Recommendation to repeal or modify all hampers or prevents effective functioning and effective control.

-Evaluation of administrative decisions to ensure compatibility with the existing legislation.

-Supervise the training and qualification of all employees in the unit and the dissemination of information and knowledge necessary for them and for the nature of the work to ensure continuity and quality.

-Any other tasks or duties related to the institution were determined by the General Director. 


\section{Analysis of Questionnaire Answers and Hypotheses Testing}

Table (1). Demographic Charactaristic (Description of functional variables of the study sample members)

\begin{tabular}{|c|c|c|c|}
\hline Question & Answer & Repeat & Percentage \\
\hline \multirow{4}{*}{ Job Title } & Internal control manager & 7 & 7.2 \\
\hline & $\begin{array}{l}\text { Director and financial } \\
\text { controller }\end{array}$ & 14 & 14.7 \\
\hline & Head of Department & 20 & 20.9 \\
\hline & Employee & 55 & 57.2 \\
\hline Total & & 96 & 100 \\
\hline \multirow{5}{*}{ Qualification } & Under Secondary & 0 & 0 \\
\hline & Diploma & 6 & 6.4 \\
\hline & BA & 80 & 83.9 \\
\hline & Master & 9 & 9.6 \\
\hline & PHD & 1 & 0.1 \\
\hline Total & & 96 & 100 \\
\hline \multirow[b]{4}{*}{ Spicialization } & Accounting & 79 & 82.2 \\
\hline & Management & 3 & 3.1 \\
\hline & Financial & 5 & 5.3 \\
\hline & Other & 9 & 9.4 \\
\hline Total & & 96 & 100 \\
\hline \multirow{5}{*}{$\begin{array}{l}\text { experience years } \\
\text { in internal } \\
\text { control in the } \\
\text { Government } \\
\text { administrative } \\
\text { units }\end{array}$} & 20 years and more & 20 & 20.8 \\
\hline & 15- less than 20 & 10 & 10.4 \\
\hline & 10- less than 15 & 40 & 41.7 \\
\hline & 5- less than 10 & 9 & 9.3 \\
\hline & Less than 5 years & 17 & 17.8 \\
\hline Total & & 96 & 100 \\
\hline \multirow[b]{2}{*}{ Workplace } & Ministry & 75 & 78.2 \\
\hline & Government Department & 21 & 21.8 \\
\hline Total & & 96 & 100 \\
\hline
\end{tabular}

Table (1) shows the functional variables of the study sample in terms of job title, qualification, specialization, experience years in the field of administrative government units, and workplace.

The results show that the proportion of senior and leadership within administrative government units of sample study (28\%) is a reasonable proportion. This is because the study included (5) Ministries (expenditure) and (2) government department (revenue). The table indicates that most employees in the study sample (different work sites, will explain later), holders of bachelor's degree (83.9\%) and Master's degree (9.6\%), shows that employees in administrative government units are qualified to conduct business efficiently and effectively. 
The table above shows that most employees who hold bachelor's degree accounting specialty, has a rate of $82.2 \%$, followed by financial (5.3\%), and followed by the number of administration employees (3) with a rate of $3.1 \%$. Furthermore, this is followed by other disciplines such as law, sociology at the rate of $9.4 \%$ which is not a high percentage of the researcher viewpoint. However, this shows that high professionalism attempted to implement administrative government units on the basis of appointments and acceptances.

For practical experience, the table above shows that most of the respondents are highly experienced in the field of internal control in the government sector. Here, the percentage of employee with experience of over 10 years was $41.7 \%$. However, this is an indication that the internal control staff in the administrative government units has enough expertise to carry out control functions and the ability to assess the effectiveness of financial control.

For the workplace, the above table shows a proportion of $78 \%$. It is reasonable from the researcher viewpoint to achieve the purpose of the study objective in spending administrative government units with a rate of $21 \%$ on the rest of the study sample of revenue of administrative government units.

\section{Analysis of the First Major Hypothesis}

In order to analyze the first major hypothesis, "internal control cannot assess the effectiveness of financial control in administrative government units."

This field consists of 20 items which was drafted by sequentially measuring the effectiveness of financial control to fit what should be a reality. Thus, the research analysis obtained data using the accounting community and standard deviations in this area.

Table (2). Descriptive statistics for responding to opinions for assessing internal control effectiveness of financial control in administrative government units

\begin{tabular}{|c|c|c|c|c|l|}
\hline No. & $\begin{array}{c}\text { Evaluation of } \\
\text { internal control } \\
\text { units for } \\
\text { financial control } \\
\text { effectiveness in } \\
\text { administrative } \\
\text { government } \\
\text { units }\end{array}$ & $\begin{array}{c}\text { Arithmetic } \\
\text { Mean }\end{array}$ & $\begin{array}{c}\text { Standard } \\
\text { Deviation }\end{array}$ & $\begin{array}{c}\text { Order of } \\
\text { importance } \\
\text { paragraph }\end{array}$ & Level \\
\hline 2 & $\begin{array}{c}\text { Internal control } \\
\text { of } \\
\text { administrative } \\
\text { government } \\
\text { units } \\
\text { independent } \\
\text { Verify the } \\
\text { validity and } \\
\text { integrity of the } \\
\text { application of }\end{array}$ & 4.326 & 0.670 & 2 & High \\
\hline & 4.062 & 1.005 & 9 & High \\
\hline
\end{tabular}




\begin{tabular}{|c|c|c|c|c|c|}
\hline & $\begin{array}{c}\text { the applicable } \\
\text { financial } \\
\text { legislation. }\end{array}$ & & & & \\
\hline 3 & $\begin{array}{c}\text { Auditing } \\
\text { expenses, and } \\
\text { make sure they } \\
\text { are disbursed } \\
\text { for the purposes } \\
\text { they are } \\
\text { allocated for. }\end{array}$ & 4.101 & 1.029 & 11 & High \\
\hline 4 & $\begin{array}{c}\text { Sufficient } \\
\text { appropriations } \\
\text { available in the } \\
\text { budget of the } \\
\text { administrative } \\
\text { government } \\
\text { units to carry } \\
\text { out functional } \\
\text { duties. } \\
\end{array}$ & 4.188 & 0.899 & 8 & High \\
\hline 5 & $\begin{array}{c}\text { Auditor } \\
\text { protected from } \\
\text { the influence } \\
\text { and powers of } \\
\text { the ministries } \\
\text { and institutions } \\
\text { under its } \\
\text { control. }\end{array}$ & 4.296 & 0.946 & 6 & High \\
\hline 6 & $\begin{array}{c}\text { Audit the } \\
\text { submitted } \\
\text { documents in } \\
\text { support of } \\
\text { exchange to } \\
\text { verify their } \\
\text { authenticity and } \\
\text { matching value. }\end{array}$ & 4.104 & 0.953 & 3 & High \\
\hline 7 & $\begin{array}{l}\text { Examination } \\
\text { and verification } \\
\text { of the validity } \\
\text { of the } \\
\text { calculation of } \\
\text { financial } \\
\text { transactions and } \\
\text { documents have } \\
\text { been enhanced. } \\
\text { This is also the } \\
\text { same for } \\
\text { documents } \\
\text { relating to } \\
\text { expenses, } \\
\text { accounting } \\
\text { guidance, the } \\
\text { validity of } \\
\text { recorded, } \\
\text { carried forward, } \\
\text { saving, and } \\
\text { which is } \\
\text { classified } \\
\text { according to } \\
\text { assets and } \\
\text { accounting } \\
\text { principles that } \\
\text { is applicable. }\end{array}$ & 4.289 & 0.891 & 3 & High \\
\hline
\end{tabular}




\begin{tabular}{|c|c|c|c|c|c|}
\hline 8 & $\begin{array}{l}\text { Internal auditor } \\
\text { gets all records, } \\
\text { documents and } \\
\text { information } \\
\text { required by the } \\
\text { controlled } \\
\text { entity. }\end{array}$ & 4.046 & 0.969 & 14 & High \\
\hline 9 & $\begin{array}{l}\text { Controlled units } \\
\text { are committed } \\
\text { to providing the } \\
\text { information at } \\
\text { the right time. }\end{array}$ & 3.714 & 1.023 & 20 & High \\
\hline 10 & $\begin{array}{c}\text { Auditing } \\
\text { payroll for } \\
\text { employees' } \\
\text { salaries, } \\
\text { deductions, } \\
\text { overtime and } \\
\text { transfers for all } \\
\text { staff categories. }\end{array}$ & 4.004 & 0.854 & 11 & High \\
\hline 11 & $\begin{array}{l}\text { Ensure the } \\
\text { safety of } \\
\text { accounting } \\
\text { entries and the } \\
\text { proper use of } \\
\text { financial } \\
\text { records. }\end{array}$ & 4.069 & 0.955 & 13 & High \\
\hline 12 & $\begin{array}{l}\text { Internal control } \\
\text { units develop a } \\
\text { detailed } \\
\text { program of } \\
\text { financial control } \\
\text { of } \\
\text { administrative } \\
\text { government } \\
\text { units. }\end{array}$ & 4.202 & 1.070 & 3 & High \\
\hline 13 & $\begin{array}{l}\text { Confirm the } \\
\text { results of the } \\
\text { financial } \\
\text { position and } \\
\text { conclusions, } \\
\text { adjustments, } \\
\text { bank pendants; } \\
\text { and the } \\
\text { contained data } \\
\text { therein are } \\
\text { correct. }\end{array}$ & 4.232 & 0.935 & 3 & High \\
\hline 14 & $\begin{array}{l}\text { Audit of the } \\
\text { administrative } \\
\text { unit's assets } \\
\text { through regular } \\
\text { inventory and } \\
\text { verification of } \\
\text { matching } \\
\text { records data } \\
\text { with the actual } \\
\text { assets. Also, the } \\
\text { material is } \\
\text { stored properly } \\
\text { and items cards } \\
\text { and indexing } \\
\text { are present so as } \\
\text { to facilitate }\end{array}$ & 3.907 & 0.943 & 17 & High \\
\hline
\end{tabular}




\begin{tabular}{|c|c|c|c|c|c|}
\hline & $\begin{array}{l}\text { access to the } \\
\text { material } \\
\text { correctly. }\end{array}$ & & & & \\
\hline 15 & $\begin{array}{l}\text { Audit records of } \\
\text { supplies and } \\
\text { material input } \\
\text { and output } \\
\text { correctly } \\
\text { reformatted. }\end{array}$ & 3.956 & 0.917 & 16 & High \\
\hline 16 & $\begin{array}{c}\text { Audit on } \\
\text { procurement } \\
\text { procedures in } \\
\text { both purchasing } \\
\text { process and the } \\
\text { extent of } \\
\text { compliance } \\
\text { with regulations } \\
\text { of the } \\
\text { Organization } \\
\text { and its } \\
\text { legislation } \\
\end{array}$ & 4.209 & 0.983 & 7 & High \\
\hline 17 & $\begin{array}{l}\text { Make sure the } \\
\text { supply of } \\
\text { purchased } \\
\text { materials and } \\
\text { commitment to } \\
\text { terms of supply; } \\
\text { and provide the } \\
\text { guarantees } \\
\text { necessary for } \\
\text { the operations } \\
\text { of purchase. }\end{array}$ & 3.866 & 0.966 & 18 & High \\
\hline 18 & $\begin{array}{l}\text { Verification of } \\
\text { public spending } \\
\text { and } \\
\text { achievement of } \\
\text { the desired } \\
\text { objectives. }\end{array}$ & 3.860 & 0.935 & 18 & High \\
\hline 19 & $\begin{array}{c}\text { Ensure the } \\
\text { integrity of data } \\
\text { and calculations } \\
\text { and information } \\
\text { processing by } \\
\text { the computer. }\end{array}$ & 4.020 & 0.945 & 15 & High \\
\hline 20 & $\begin{array}{l}\text { Data analysis, } \\
\text { verification and } \\
\text { validation of the } \\
\text { financial and } \\
\text { accounting } \\
\text { records relating } \\
\text { to income and } \\
\text { expenses were } \\
\text { in accordance } \\
\text { with laws and } \\
\text { regulations, and } \\
\text { financia } \\
\text { accounting } \\
\text { systems. } \\
\end{array}$ & 4.788 & 0.767 & 1 & High \\
\hline \multicolumn{2}{|c|}{$\begin{array}{l}\text { The arithmetic mean and general } \\
\text { standard deviation }\end{array}$} & 4.099 & 0.511 & - & High \\
\hline
\end{tabular}


Table (2) shows the answers of the study sample in the administrative government units. This is about the statements concerning the evaluation of internal control units for effective financial control in administrative government units. Here, the arithmetic ranging for this variable is between 3.714-4.788, with an overall average of 4.099 on a penta likert scale. Thus, this indicates the high-level of evaluation of the effectiveness of internal control units of financial control in the administrative government units.

Paragraphs 20,1 states that "data analysis, verification and validation of the financial accounting records relating to income and expenses were in accordance with laws and regulations. Also, the "Internal control of administrative government units independent" occupied first and second order respectively with an average arithmetic mean of 4.788-4.329. Hence, this is higher than the arithmetic mean (4.032) and standard deviation (0.511). On the other hand, the statement "Controlled units are committed to providing the information at the right time" got the twentieth and last rank with arithmetic average (3.714). Consequently, the lowest of the arithmetic total is 4.099 and the standard deviation is 1.023 . This demonstrates the need to activate the greater role of internal control in other departments and administrative units under its control, particularly in those aspects.

Therefore, it has agreed and supported this hypothesis due to other studies findings such as the study of Abu-dalbouh (2012) and Cahill (2006).

\section{Analysis of the Second Major Hypothesis}

There are no impediments limiting the assessment of internal controls for the effectiveness of financial control in administrative government units. Table (3). Descriptive statistics responding to the opinions about the impediments which

limit the effectiveness of internal control for financial control in the administrative government units rating

\begin{tabular}{|c|c|c|c|c|c|}
\hline No. & $\begin{array}{l}\text { There are no } \\
\text { impediments } \\
\text { limiting the } \\
\text { assessment of } \\
\text { internal controls for } \\
\text { the effectiveness of } \\
\text { financial control in } \\
\text { administrative } \\
\text { government units. }\end{array}$ & $\begin{array}{c}\text { Arithmeti } \\
\text { c Mean }\end{array}$ & $\begin{array}{l}\text { Standard } \\
\text { Deviation }\end{array}$ & $\begin{array}{l}\text { Order of } \\
\text { importance } \\
\text { paragraph }\end{array}$ & Level \\
\hline 21 & $\begin{array}{l}\text { Routine financial } \\
\text { transactions to be } \\
\text { performed on a } \\
\text { daily basis. }\end{array}$ & 3.920 & 1.003 & 1 & High \\
\hline 22 & $\begin{array}{l}\text { Lack of experience } \\
\text { in financial } \\
\text { accounting areas. }\end{array}$ & 3.606 & 1.407 & 5 & middle \\
\hline 23 & $\begin{array}{l}\text { Number of working } \\
\text { hours required in } \\
\text { the implementation }\end{array}$ & 3.707 & 0.940 & 3 & High \\
\hline
\end{tabular}




\begin{tabular}{|c|c|c|c|c|c|}
\hline \multirow{2}{*}{\multicolumn{6}{|c|}{\begin{tabular}{l|l} 
& of work \\
\end{tabular}}} \\
\hline & & & & & \\
\hline 24 & $\begin{array}{l}\text { Lack of incentives } \\
\text { and benefits. }\end{array}$ & 3.912 & 1.056 & 2 & High \\
\hline 25 & $\begin{array}{l}\text { Accounting and } \\
\text { technological } \\
\text { regulations used in } \\
\text { administrative } \\
\text { government unit. }\end{array}$ & 3.453 & 1.036 & 8 & middle \\
\hline 26 & $\begin{array}{l}\text { Lack of harmony } \\
\text { with the nature of } \\
\text { business finance } \\
\text { specialization. }\end{array}$ & 3.488 & 1.026 & 7 & middle \\
\hline 27 & $\begin{array}{l}\text { Obsolescence of } \\
\text { certain laws, } \\
\text { regulations, } \\
\text { instructions, and not } \\
\text { to modify them but } \\
\text { keep them up with } \\
\text { development. }\end{array}$ & 3.028 & 1.012 & 10 & middle \\
\hline 28 & $\begin{array}{c}\text { Lack of } \\
\text { management } \\
\text { attention to the } \\
\text { training side, } \\
\text { courses, and } \\
\text { monthly and annual } \\
\text { lectures. }\end{array}$ & 3.337 & 1.149 & 9 & middle \\
\hline 29 & $\begin{array}{l}\text { The Department } \\
\text { did not respond to } \\
\text { the reports and what } \\
\text { came out of the } \\
\text { modifications and } \\
\text { enhancements. }\end{array}$ & 3.707 & 1.113 & 3 & High \\
\hline \multirow[t]{2}{*}{30} & $\begin{array}{c}\text { Less experience in } \\
\text { leadership and } \\
\text { weaknesses when } \\
\text { making } \\
\text { administrative and } \\
\text { financial decisions. }\end{array}$ & 3.522 & 1.622 & 6 & middle \\
\hline & $\begin{array}{c}\text { The arithmetic } \\
\text { mean and general } \\
\text { standard deviation }\end{array}$ & 3.551 & 0.610 & - & middle \\
\hline
\end{tabular}

Table (3) shows answers of the study sample in the administrative government units for phrases related to impediments that limit the internal control of the effectiveness of financial control in the administrative government units. Here, the arithmetic range for this variable is between 3.028-3.920 with an overall average of 3.551 on penta likert scale. Consequently, this refers to the average level of impediments to assess the internal control effectiveness of financial control in administrative government units. 
Paragraph (21) states the "Routine financial transactions to be performed on a daily basis" with an average arithmetic mean (3.920). This, therefore, is higher than the general arithmetic mean (3.551) and standard deviation (1.003).

Paragraph (27) "Obsolescence of certain laws, regulations, instructions, and not to modify them but keep them up with development" got the tenth and last place with average arithmetic mean of 3.028. Thus, this is lower than the general arithmetic (3.551) and standard deviation (1.012).

In general, it shows that the impediments that limit the evaluation of internal control effectiveness of financial control in administrative government units under consideration from study sample viewpoint were moderate. This is because the above limitations do not constitute an obstacle to the work of the internal control units. Paragraphs $(23,29)$ represent an obstacle from the respondent's viewpoint which reduces the internal control units when they assess the financial control administrative government units. On the other hand, it has agreed and supported this hypothesis as a result of other studies findings such as the study of Kevin (2003) and Robyn (2014).

\section{Hypotheses Test}

\section{First Major Hypothesis}

H01: Internal control cannot assess the effectiveness of financial control in administrative government units.

In testing this hypothesis, the researcher used T-test for one sample. This is used to verify the internal control assessment of the effectiveness of financial control in the administrative government units as shown in Table (4).

Table (4). T-test results to verify the effectiveness of internal control for financial control in administrative government units evaluated

\begin{tabular}{|c|l|c|c|l|l|l|l|}
\hline $\begin{array}{c}\text { First major } \\
\text { hypothesis }\end{array}$ & NO. & $\begin{array}{c}\text { Arithmetic } \\
\text { Mean }\end{array}$ & $\begin{array}{c}\text { Standard } \\
\text { Deviation }\end{array}$ & DF & $\begin{array}{c}\text { Calculated } \\
\text { T value }\end{array}$ & $\begin{array}{c}\text { Tabulated } \\
\text { T Value }\end{array}$ & Sig* \\
\hline $\begin{array}{c}\text { Internal } \\
\text { control } \\
\text { assessment } \\
\text { for the } \\
\text { effectiveness } \\
\text { of financial } \\
\text { control in } \\
\text { administrative } \\
\text { government } \\
\text { units }\end{array}$ & 96 & 4.099 & 0.511 & 85 & 15.622 & 1.051 & 0.000 \\
\hline
\end{tabular}

Demonstrated by the results shown in the table (4), the financial control in government administrative units functioning is based on an assessment of the internal control units at the significance level $(\alpha \leq 0.05)$. 
The calculated T- value function is 15.622 and the indication level is given as $\alpha \leq 0.05$ when compared with Tabulated $T$-Value (1.051). The table also shows the same level indication (0.000). As a result, the internal control can assess the effectiveness of financial control in the administrative government units.

The premise of nihilism (zero) is accepted and the alternative hypothesis is rejected if the calculated value is less than the tabular value and the moral (Sig) is greater than 0.05 . Also, the null hypothesis $\left(\mathrm{H}_{\mathrm{O}}\right)$ is rejected if the calculated value is greater than the tabular value. On the other hand, if the value of the moral (Sig) is less than 0.05 , we reject the null hypothesis and accept the alternative hypothesis. Thus, this hypothesis states that:

"Internal control can assess the effectiveness of financial control in administrative government units."

\section{Second Major Hypothesis}

H02: There are no impediments limiting the assessment of internal controls for the effectiveness of financial control in administrative government units.

To test this hypothesis, the researcher used T-test for one sample, in order to verify the impediments limiting the assessment of internal controls for the effectiveness of financial control in administrative government units. Thus, this is as shown in Table (5).

Table (5). T-test results to verify the impediments limiting the assessment of internal controls for the effectiveness of financial control in administrative government units

\begin{tabular}{|c|l|l|l|l|l|l|l|}
\hline $\begin{array}{c}\text { Second major } \\
\text { hypothesis }\end{array}$ & NO. & $\begin{array}{c}\text { Arithmetic } \\
\text { Mean }\end{array}$ & $\begin{array}{c}\text { Standard } \\
\text { Deviation }\end{array}$ & DF & $\begin{array}{c}\text { Calculated } \\
\text { T value }\end{array}$ & $\begin{array}{c}\text { Tabulated } \\
\text { T Value }\end{array}$ & Sig* \\
\hline $\begin{array}{c}\text { Impediments } \\
\text { limiting the } \\
\text { assessment of } \\
\text { internal } \\
\text { controls for } \\
\text { the } \\
\text { effectiveness } \\
\text { of financial } \\
\text { control in } \\
\text { administrative } \\
\text { government } \\
\text { units }\end{array}$ & 96 & 3.551 & 0.611 & 85 & 8.758 & 1.669 & 0.000 \\
\hline
\end{tabular}

Demonstrated by the results shown in the table (5), the impediments limiting the assessment of internal controls for the effectiveness of financial control in administrative government units has a significance level ( $\alpha \leq$ 0.05).

The calculated T- value function is 8.758 and the indication level is $\alpha$ $\leq 0.05$, when compared with tabulated $\mathrm{T}$-Value (1.669). The table also 
shows the same level indication (0.000). As such, there is impediments limiting the assessment of internal controls for the effectiveness of financial control in administrative government units.

\section{Third Major Hypothesis}

Using (One Way Anova) analysis of variance for the third hypothesis, it stipulates that: "There were no statistically significant differences in the study sample answers attributed to the experience, qualifications and position regarding the effectiveness of financial control in administrative government units." Here, the level of indication $(\alpha \leq 0.05)$ is related to the assessment of the effectiveness of internal control for financial control in the administrative government units according to the difference of experience, qualification, and position. It has been shown that there were no statistically significant differences in the study sample answers attributed to the experience, qualifications, and position of the assessment of the effectiveness of internal control of financial control in administrative government units. This is because the Tabulated - $\mathrm{F}$ for each demographic properties were larger than the calculated F. Here, qualifications as an example achieved Tabulated-F (3.601) compared with the calculated-F (4.994) at the level of significance $(\alpha \leq 0.05)$ and by SOS (7.960). This, however, continues for other demographic characteristics with differing numbers of analysis.

Depending on the ruling base, the hypothesis of nihilism is accepted (Ho) if the calculated value is less than the tabulated value. On one hand, if the mental value ( $\mathrm{Sig}$ ) is greater than 0.05 , the hypothesis of nihilism (Ho) is rejected. On the other hand, if the calculated value is greater than the value of tabular, mental value (Sig) less than 0.05 , the hypothesis of nihilism (Ho) is accepted. Thus, this hypothesis states: "There were no statistically significant differences in the study sample answers attributed to the experience and qualifications, and position regarding the effectiveness of financial control in administrative government units at indication level $(\alpha \leq$ 0.05)."

\section{Study Result} of results:

Based on data analysis and hypothesis testing, the study found a set

1. Evaluation of internal control units for effective financial control in administrative government units typically come with a high degree with average arithmetic (4.099) and standard deviation (0.511). The researcher attributed this result to the data analysis. The verification and validation of the financial and accounting records relating to income and expenses were in 
accordance with financial laws and regulations and the prescribed accounting for financial controls.

2. The impediments that assess internal control effectiveness for financial control in the administrative government units generally came with moderately and average arithmetic (3.551) and standard deviation (0.610). Therefore, the researcher attributed this result to the presence of some of the most important obstacles as follow: .

-. Routine work

-. Lack of incentives and benefits

-. Lack of management response to reports

-.Number of hours needed to perform the work

3. Internal control can assess the effectiveness of financial control in administrative government units for internal control units by the amount of its commitment to the rules and regulations and financial instructions provided in the Jordanian regime.

4. There are impediments limiting the assessment of internal controls for effectiveness of financial control in the administrative government units.

5. There were no statistically significant differences in the study sample answers attributed to the experience and qualifications, and position regarding the effectiveness of financial control in the administrative government units at the level indication $(\alpha \leq 0.05)$.

\section{Study Recommendations}

In light of the above, the researcher provides a set of recommendations:

1. Attention to the human element as one of the main components of the internal control system in terms of training and development, and keeping them up with scientific and practical progress.

2. Emphasize the need to reformulate some of the legislation and instructions for some of the financial aspects.

3. Work on the development of strategies and plans of financial control. Also, it should take into account the availability of experiance, skills and capabilities of the managers, and the employees of administrative government units.

4.The need for harmonization between the legislation and regulations with international professional standards especially the supreme control standards of what lends importance and effectiveness to financial control. 


\section{References:}

Al Dosari, Mohammed Mubarak (2011). Assessing the impact of the financial control exercised by Audit Bureau on the public institutions in Kuwait State, Master Thesis, University of the Middle East, Jordan.

Alkaaabr \& Mahmoud Khaled (2013). Appropriateness of audit procedures to fight corruption, Unpublished MA Thesis, University of the Middle East, Jordan.

Abu Dalbouh \& Walid Majid (2012). The impact of effective financial control over the financial performance of independent public institutions of Jordan, Master Thesis, Al al-Bayt University, Jordan.

Arab Group of Supreme Accounting Control (1996.219).

Arab Organization of Supreme Audit Institutions (Arabosai, 2000).

Arab Organization of Supreme Audit Institutions (Arabosai, 2006).

Arab Organization of Supreme Audit Institutions (Arabosai, 2012).

Beasley et al. (2006). The Impact of Enterprise Risk Management on the Internal Audit Function.

Cahill \& Edward (2006). Audit committee and internal audit effectiveness in a multinational bank subsidiary: A case study. Journal of banking regulation, vol 7 p160-179.

Faudziah et al. (2005). Internal auditing practices and internal control system, managerial auditing journal, volume.(20), issue 8, pp 844 866.(Electronic copy).

Gerrit Sarens (2007). The role of internal auditing in corporate governance: qualitative and quantitative insights on the influence of organizational characteristics, Dissertation doctor.

Ghaith \& Ezat (2002). The Hashemite Kingdom's Constitution and Amendments of 1952, a series of judicial legislation (1), Dar Qandil Publishing and Distribution, Amman, Jordan, p 54.

Ghneimat et al. (2011). Factors affecting the effectiveness of internal control systems in the Jordanian ministries, the magazine of Jordan in Business Administration, Vol. 7, No. (4), Amman, Jordan.

Institute of Internal Auditors IIA (2004). Code of ethics and standards for the professional practice of Internal Auditing.

Institute of Internal Auditors IIA (2010).

Institute of Internal Auditors IIA (2011). Internal Auditing Role in Risk Management.

International standards for devices Supreme Audit Institutions, issued by The International Organisation of Supreme Audit Institutions (INTOSAI) 2006.

Kevin (2003). The Effects of Internal Audit Structure on Perceived Financial Statement Fraud Prevention, Accounting Horizons, Vol. 17, No.4, pp. 1-17. 
O'Regan \& David (2001). Genesis of a profession: towards professional status for internal auditing, Managerial Auditing Journal. Vol. (16) No. (4) 2001 pp. 215-226.

Philip Linsley (2005). M. Page and L. Spira, The Turnbull Report, Internal Control and Risk Management: The Developing Role of Internal Audit, The Institute of Chartered Accountants of Scotland, Edinburgh (2004) (130 pages, £15.00). The British Accounting Review, Vo.37, Issue 3, Pp354-355. Rashid et al. (2012). The effectiveness of financial control system and its impact on financial corruption in Iraq: A Case Study of the University of Mosul.

Sawalha et al. (2013). Renewed senior government control methods according to the requirements of the privatization: A Case Study in Jordan. Journal of Baghdad College of Economic Sciences, No. 36, Iraq 2013.

Smith david, Jones, \& Deborah (2000). Strengthening Internal controls Armed forces comptroller, volume (45), issue 3, P. 339.(electronic copy).

The Hashemite Kingdom of Jordan, Audit Bureau Law, Official Newspaper No. 1105, 16/04/1952, No. 4533, 17.2.2002, No. 605, 17/2/2002 Audit Bureau, Amman, Jordan.

The Hashmiate Kingdom of Jordan- CSC 0 (2013).

The Ministry of finance, Applied FAQ for Financial Affairs No. 1/1995, Administrative Development and Training Directorate, Amman, Jordan, updated, S94-96. 